\title{
The effect of Phet Simulation media for physics teacher candidate understanding on photoelectric effect concept
}

\author{
Supurwoko ${ }^{a}$, Cari ${ }^{\mathrm{b}}$, Sarwanto, Sukarmin, Suparmi. \\ ${ }^{a}$ Lecturer at graduate program of science education, \\ Sebelas Maret University, INDONESIA. \\ ${ }^{\mathrm{b}}$ Lecturer at doctorate program of science education, \\ Sebelas Maret University, INDONESIA.
}

Corresponding e-mail : supurwoko@ staff.uns.ac.id,$\underline{\text { supurwoko@ gmail.com }}$ supurwoko@yahoo.com

\begin{abstract}
Indonesian new Curriculum for senior high school students required student-centered learning. One of the curriculum implementation constraint was the difficulty of providing learning media. PhET simulations media is one of the options that can help implementation of new curriculum on learning. However, the use of this media in Indonesia still needs to be studied comprehensively. The learning was conducted on students of physics education Study Program in sebelas maret university in 2013. The sample consisted of 62 students that was taking quantum physics course. The method that was used in the research was descriptive qualitative. The method that was used in learning was demonstration's method that used PhET media and accompanied by a question and answer and groups discussion. The data was collected using multiple choice test and interview through email. We found that any students still did not understand about photoelectric effect concept. They were confused when asked about the thick material and cross section of the targets as related with the regardless of electrons in the photoelectric effect event. Other than that, the concept of the waves as a particle and its relation with the kinetic energy of the electrons was not understood by most students.
\end{abstract}

\section{Introduction}

The photoelectric effect is a subject that should be taught to the $12^{\text {th }}$ class natural science senior high school. This subject is a compulsory subject in the new curriculum that was developed by Indonesian government. While at physics education Study Program in sebelas maret university, the photoelectric effect is a part of modern physics lecture that was taught at $5^{\text {th }}$ semester and quantum physics that was taught at $6^{\text {th }}$ semester.

The photoelectric effect is one of the phenomenon that underlie the birth of quantum physics. This phenomenon involves micro-sized materials that can't be observed with the unaided eye, abstract and complex (McKagan, 2008). The abstract nature caused a problem in the classroom. Students were not able to interact with the phenomenon that was studied so that there was no feedback that amplified or straightened student's understanding that had misconception. This problem caused the students did not 
understand the concept and just memorized the equations that were given by the teacher. this problem caused the students opportunist and uncreative (H. Wang, 2010).

H Müller and R Wiesner (2002) had researched quantum physics teaching for physics teachers at senior high school used virtual labs and WEB. The research results showed that quantum physics learning with virtual labs could reduce misconceptions that occur as a result of classical learning in atom concept, properties of quantum mechanics and the uncertainty principle. McKagan's research results showed that PhET quantum simulations that was designed to overcome the student difficulties in quantum mechanics effectively helped the students understanding about the abstract concepts of quantum mechanics. T Civeleka and E Ucar (2012) found that the used of physics experimental simulation method is more effective than traditional teaching methods.

Based on the description above, we would examine the understanding of senior high school physics teacher candidates on the concept of photoelectric effect after they learned by using PhET computer simulations media that was downloaded on March $3^{\text {rd }}$, 2016. The indicators that would be assessed are: 1) Student's understanding about the factors that influenced electron's release on the photoelectric effect; 2) Student's understanding about particle properties of electromagnetic waves. The method that was used in learning was demonstration's method with PhET media. The method that was used in the research was descriptive qualitative. Data was obtained by using triangulation method through multiple-choice test, questionnaire and interview. Sample was divided into two groups. There were the top and the bottom group.

\section{Theoretical framework}

\subsection{PhET simulations Media}

PhET Quantum simulations is a software that was created by S. B. McKagan et al. The software was designed to overcome student difficulties in understanding the photoelectric effect. The main feature of the PhET is visualization simulations, interactivity, contextual, and using the effectively calculations to help students understanding the abstract concepts and the uncertainty in quantum mechanics. PhET views of the software is shown in Figure 1. 


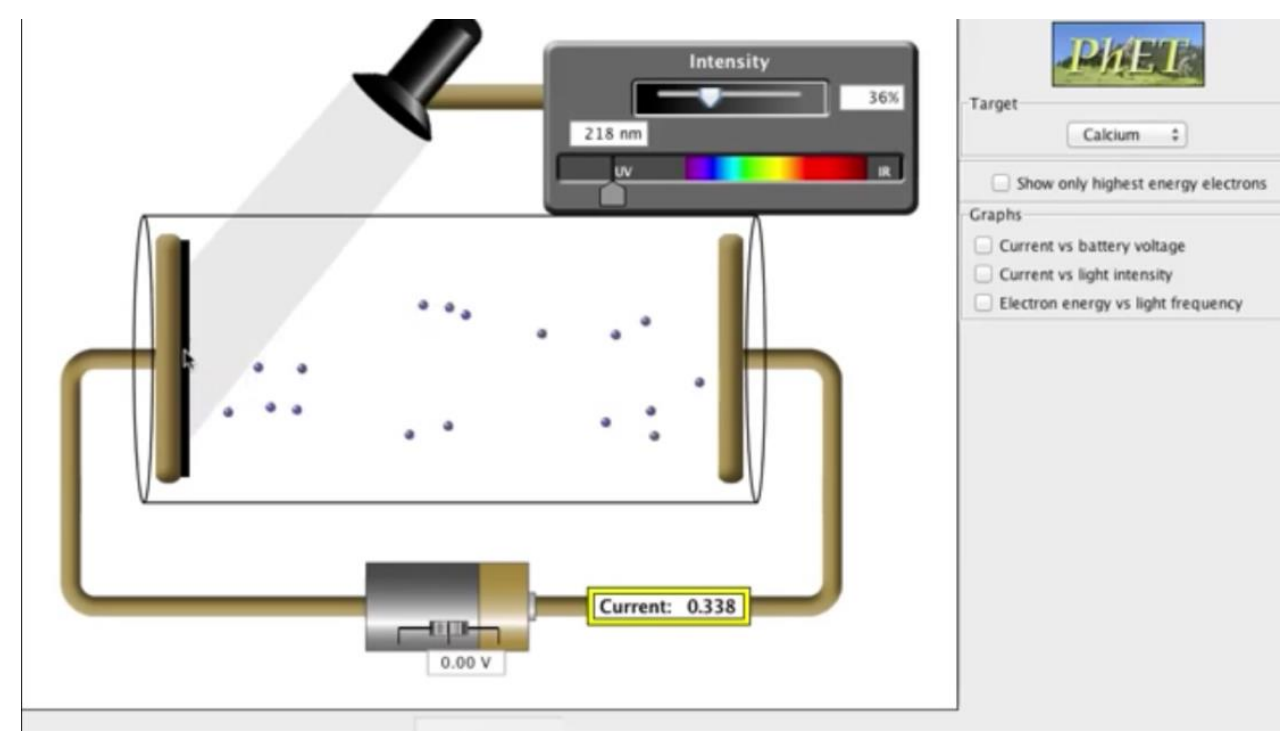

Figure 1: PhET views of the software.

Learning using PhET simulations was including multimedia learning. Multimedia learning was learning used verbal and pictorial information (Mayer, 2005; Mayer, 2002). The message forms of verbal information could be a text or a narration. While the pictorial information could be static images (such as photos or illustrations) or dynamic (such as video and animation).

Multimedia could transform the abstract concepts into concrete. it could help the students understanding the abstract concepts that was difficult to imagine (Betrancourt and Tversky, 2000). Visualization allowed students interacted, reacted and communicated so the information could come more durable into their memory and easy to recall.

\subsection{Learning the photoelectric effect}

Photoelectric effect was one of the events that determined the changes of physics concept at atomic scale. This event could be explained if the electromagnetic waves was treat as particle (Lloyd, 2015). The particle was called photon. When electromagnetic wave hit an electron that was bounded in a metal, the energy would be absorbed by electron if the energy was greater than or equal to the electron binding energy. The absorption caused the electrons detached from the metal. Conversely, if the energy was lower than the electron binding energy, the electrons would not be separated from the metal atom (Yousif, 2015). This phenomenon is shown by the graph in Figure 2. 


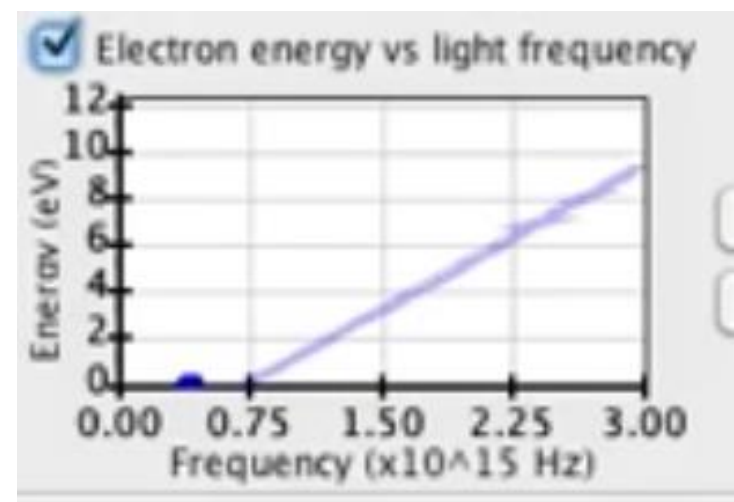

Figure 2: The Graph that showed the relationship between electromagnetic energy and the emitted electrons energy on the photoelectric effect.

\section{Research methods}

This research was conducted using qualitative descriptive method. Samples of the research are students of physics education Study Program in sebelas maret university in 2013. The sample consisted of 62 students that was taking quantum physics. Samples could be considered as represented the prospective teachers in Indonesia because majority of the graduates worked as a teacher and spread almost throughout the provinces in Indonesia.

The method that was used in learning was demonstration's method that came with PhET media and accompanied by a question and answer and groups discussion. The media that was used in learning is PhET computer simulations media. Data analysis was performed using triangulation. Data were divided into two groups. There were the top and the bottom group.

\section{Discussion}

Most of the students (94\%) knew that the factors caused the release of electron in the photoelectric effect were the frequency and the work function of metal. But some students still did not understand about the concept of photoelectric properly. This is demonstrated by the fact that $31 \%$ of the top group students explained that the thick of metal influenced the release of electron in photoelectric effect. Some argued that if the metal was thick, the attractive force between electrons was getting strong so that the metal became more difficult to release the electron. Some had the opinion that if the metal is getting thicker, the atoms bonding getting stronger so the electrons increasingly difficult regardless. Some argued that if the metal is getting thicker, the chances of the photoelectric effect is getting smaller because of electromagnetic wave energy increasingly decreases when getting in through metal. While in the bottom group, 35\% of students answered that the thick of metal influenced the release of electron on photoelectric effect. Most students were not able to explain why the thick of metal was a factor that influenced the release of electrons on the photoelectric effect. However, some of students argued that the concept of photoelectric effect was similar to the X-ray transmission. When electromagnetic waves passed through a metal, the energy of the 
waves decreased because of barrier of the materials, so the chance of getting photoelectric effect was smaller. an example of student answers given in Figure 3.

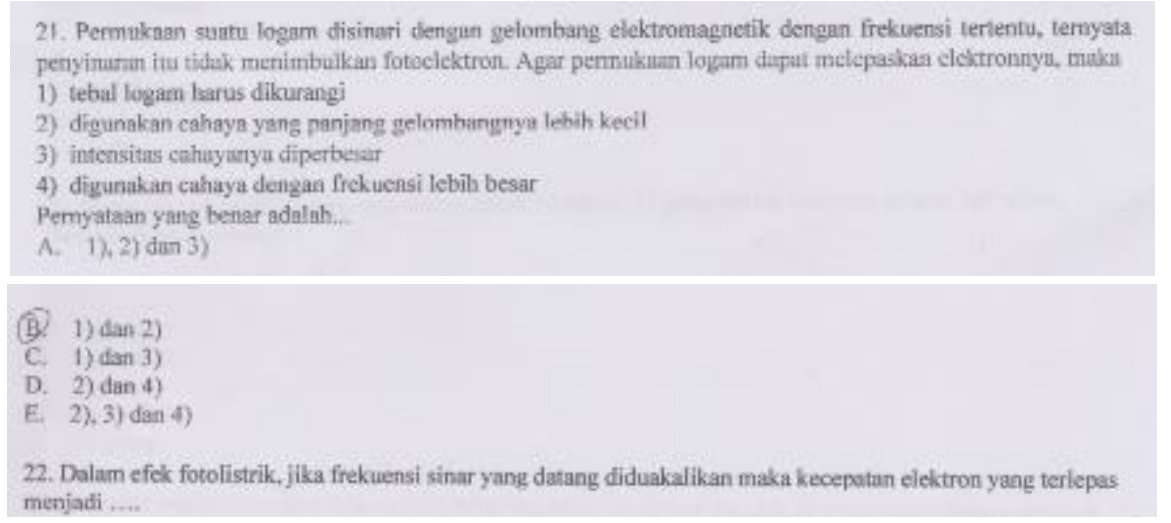

Figure 3. an example of student answers.

According the students, In addition to the thick of metals, surface area of the metal influenced the release of electrons too. $35 \%$ of the bottom group and $34 \%$ of the top group chose the surface area of the material was a factor that affects photoelectric effect. They argued that the more radiation on the material, the more the chances of the photoelectric effect because of the more greater the possibility of collisions between photons and electrons of an atom (Figure 4 and Figure 5).

Another problem that poorly understood was a concept of electromagnetic waves as photons. As many as $44 \%$ students from the bottom group and $11 \%$ students from the top group didn't understand the concept of a wave as a photon. the Interview result showed that the student of the top group mistranslate the questions. While the bottom group argued that if a growing number of photons struck the metal, the chances of having photoelectric effect getting bigger. Some did not have a reason why they choose the intensity of photons was the factor that determined the release of electrons at photoelectric effect.

1. menurut saya dengan semakin tebal logam maka semakin kuat gaya tarik-menarik antar elektron sehingga logam yang disinari akan lebih sulit melepaskan elektronya

2. karena dengan semakin luas logam maka jangkauan energy foton tidak dapat menjangkau luasan logam secara maksimal sehingga energy yang diperlukan untuk menjangkau luasan yang lebih besar juga harus diperbesar.

Terkirim dari Yahoo Mail. Dapatkan aplikasinya

Figure 4. The example of the top group students answers about the influence of the thick of metal and cross-sectional area on photoelectric effect. 
Jawaban Kuisioner Efek Fotolistrik (4)

Orang

supurwoko MSi Menurut anda luas permukaan mempengaruhi terjadinya efek fotolistrik, kenapa? tolong jelaskan ya. Pada

supurwoko MSi Menurut anda luas permukaan mempengaruhi terjadinya efek fotolistrik, kenapa? tolong jelaskan ya. Pada

karena ketika foton menumbuk permukaan suatu bahan, hal itu mempengaruhi terlepasnya elektron pada peristiwa efek fotolistrik. semakin besar luas permukaan yang ditumbuk foton maka semakin banyak pula elektron yang terlepas, dan sebaliknya. semakin sempit luas permukaan yang ditumbuk foton, maka semakins sedikit pula elektron yang terlepas dari bahan tersebut

Figure 5. The results of interviews with students about the influence of cross-sectional area on photoelectric effect

\section{Conclusion}

From the discussions above, it can be concluded that after obtaining the learning used demonstration method with PhET simulation program, most of the students was able to explain the factors that influence of the release of electron on photoelectric effect. However they still confuse whether the thick of target material and the cross section of the material influenced the release of electrons from the metal. some lower group students still confuse on understanding the concept of the waves as particle. They still did not understand the link between the intensity of the electromagnetic wave radiation with the intensity of photons.

\section{Acknoledgement}

This research is part of research funded by the UNS PNBP.

\section{Reference}

[1] A. Baddeley, (1992). Science. New Series. 255(5044), 556-559.

[2] A. Beiser.1983. Konsep Fisika Modern (Terjemahan). Jakarta. Erlangga

[3] B. K. Given. 2007. Brain Based Teaching. PT Mizan Pustaka. IKAPI.

[4] D. R. Lloyd. 2015. American Journal of Physics Am. J. Phys., Vol. 83, No. 9, 765-772.

[5] F. Paas, J. J. G. van Merriënboer. (1994). Journal of Educational Psychology, $86(1), 122-133$.

[6] J. Sweller, J. J. G. V. Merriënboer. (1998). Educational Psychology Review. 10(3), 251-296.

[7] J. Sweller. (2004). Instructional Science. 32(1/2), 9-31.

[8] M. Bétrancourt, B. Tversky. 2000. Le Travail Humain, 63, 311-329.

[9] M. E. Yousif, 2015, IJFPS, Vol 5, No 1, pp 18-31, March , 2015.

[10] P. S.Tambade, 2011, Europian Journal of Applied Sciences 3 (4) : 117 - 124. ISSN 2079-2077. 
[11] R. E. Mayer, R. Moreno. (2003). Educational Psychologist, 38(1), 43-52.

[12] R. E. Mayer. (2005). Cognitive theory of multimedia learning. The Cambridge handbook of multimedia learning, 31-48.

[13] S. Feinberg, M. Murphy. (2000). Proceedings of 2000 Joint IEEE International and 18th Annual Conference on Computer Documentation. (IPCC/SIGDOC 2000). 353-360. IEEE.

[14] S. Kalyuga. (2009). Managing cognitive load in adaptive multimedia learning. London: IGI Global.

[15] S. Klassen. 2011. Sci \& Educ (2011) 20:719-731.

[16] S. B. McKagan, K. K. Perkins. 2008, PACS numbers: 01.40.Fk,01.40.G,01.40.gb,01.50.ht.

[17] T. Civeleka, E. Ucar, 2012, Social and Behavioral Sciences 47 ( 2012 ) 1780 1786 